\title{
DEALING WITH MONASTIC REFORMS: A STUDY ON THE DEBATE OVER 'THERAVADA BHIKKHU KATHIKAWATH (REGISTRATION) BILL' IN SRI LANKA
}

\author{
Nuwan Herath ${ }^{1}$ \\ ${ }^{1}$ General Sir John Kotelawala Defence University
}

\begin{abstract}
In the context of institutionalized Buddhism, the position of the Buddhist monks in Sri Lankan society and the issues of their discipline have been commonly discussed and frequently debated with reference to various practices such as the involvement of monks in politics, acting militantly in public places, engaging in occult activities, and conducting trade or business activities, etc. One relatively recent event, which intensified discussions and debates on some of such activities, has been the introduction of the draft bill "The Theravada Bhikkhu Kathikawath" to the Parliament of Sri Lanka in January 2016. It marked a sudden outbreak of competing views from various segments of the lay and monastic societies on the position of Buddhist monks and the monastic reforms required on certain behavioral conducts. This study adopted a thematic analysis, which intended to explore what themes became more contentious in print and electronic media during the debate; and critically looked into how actors relevant to such contentious themes highlighted matters related to the Bill in particular and monastic reforms in general while falling into different discursive spaces. The debate uncovered several underlying problems related to the draft bill, monastic reforms and monastic community that include disagreements over the legitimacy of Mahanayakas or Chief Prelates and the lay political leadership, contradictions over the constitutionality of the draft bill; and problems over traditionalism and modernization of the Buddhist monastic community in Sri Lanka.
\end{abstract}

Keywords: Monastic Reforms, Buddhism, Monks, Modernization

\section{Background of the Study}

This study explored the themes that became contentious during a social debate over Buddhist monks' social position and behavior, with close attention on how actors involved in the debate fell into different discursive spaces while uncovering several underlying problems related to the state of affairs in Buddhist monastic life in Sri Lanka. In the context of institutionalized Buddhism, the position of the Buddhist monks in Sri Lankan society and the issues of their discipline have been commonly discussed and frequently debated with reference to various practices. They include activities such as the involvement of monks in politics, leading political parties, contesting for elections, acting militantly in public places, engaging in occult activities, and conducting trade or business activities, etc. The most recent event, which intensified discussions and debates on some of these activities, has been the introduction of the draft bill "The Theravada Bhikkhu Kathikawath" to the Parliament of Sri Lanka in January 2016. The bill proposed a framework for every monk to comply within a set of disciplinary guidelines decided by the monk's particular sect, chapter or 'Nikaya'. It marked a sudden outbreak of competing views from various segments of the lay and monastic societies on the position of Buddhist monks in Sri Lankan society, their activities and the monastic reforms required on certain behavioral conducts.

When looking at the history, the term 'Bhikkhu Kathikawath' can be defined as consensually arrived codes of conduct by monks, which have been put into a form of official status with the assistance of lay political 
leadership, in order to regulate or standardize the behavioral conduct of the members of the Buddhist monastic community. Such practices have taken place in several periods in Buddhist history of the country, particularly with the patronage of kings, such as Pollonaru Kathikawatha, Dambadeniya Kathikawataha etc. where disciplinary guidelines for monks were given official status in the state and violation of the guidelines had led to punishments from the monastic community or from the state depending on their severity. This paper, however, is not an attempt to trace the history of Kathikawath or go into details about the matters explained in Kathikawath. Rather it intends to explain about a social debate that came into being as a result of a relatively recent effort to make legal provisions to formulate a new Bhikkhu kathikawath for different sects, chapters or 'Nikayas' of Buddhists monks in Sri Lanka, mainly with the current government's patronage.

This bill was published in the Gazette on $14^{\text {th }}$ December 2015 and presented to the Parliament of Sri Lanka on $12^{\text {th }}$ January 2016 by the Minister of Buddhasasana. In various monastic sects, there are already formulated Kathikawath yet they do not have any legal status or power of enforcement in state's legal framework. Therefore, this bill was an attempt to give whatever the Kathikawath a formal status within the state's legal framework by properly registering them under the Commissioner General of Buddhist affairs; and enabling inquiries and punishments on Bhikkus who violate the provisions in registered Kathikawath or codes of conduct.

According to the proposed bill, the possible violations in Bhikku Kathikawath may include monks involving in "occult activities, trade or business activities, obtaining driving license and driving vehicles, engaging in any employment in the public or private sector other than in the fields of education, social services or religious affairs; engaging in activities unsuitable for a monk in public places". The punishments proposed in the bill are - "temporary/permanent expulsion from the residing temple, temporary/permanent removal from the office of Chief Incumbent position / Viharadhipathy, expulsion from the studentship, expulsion from the relevant Nikaya or chapter and cancellation of the Bhikkhu registration". In addition, if a monk fails to submit to the given punishment he will be convicted in a magistrate court with a fine no less than fifty thousand rupees or six-month imprisonment or else both punishments together. Such given proposals in the Kathikawath bill marked a sudden outbreak of competing views from various segments of the lay and monastic societies on the position of Buddhist monks in the country.

This study, however, does not map all the competing views that expressed during the debate rather it intended to explore what themes became more contentious, among others, in print and electronic media during the debate; and looked into how actors relevant to such contentious themes highlighted matters related to the Bill in particular and monastic reforms in general while falling into different discursive and argumentative spaces. In order to answer these questions, a thematic analysis has been adopted and the main contentious topics that foregrounded the argumentative space have been framed as (1) Legitimacy of Mahanayakas or Chief Prelates (2) Government and Political Leaders' legitimacy (3) Contradictions over the constitutionality of the draft bill; and (4) Problems of traditionalism and modernization of the Buddhist monastic community in Sri Lanka.

\section{Legitimacy of Mahanayakas}

The Social debate of 'Theravada Bhikkhu Kathikawath' has led to the contestation of the legitimacy of 'Mahanayakas' or the Chief Prelates of different Nikayas and the lay political leadership of the country as credible actors of taking leadership for constituting Bhikkhu Kathikawath. Right from the beginning, it was quite evident that the Mahanayakas and the lay political leadership had mutually authorized each other's role and recognized the importance of their intervention at this conjuncture. For example, both President and Prime Minister along with other ministers have repeatedly mentioned that further amendments or enactment of the bill would be done with the advice and the consent of the Mahanayakasi. On the other hand, the Mahanayakas' views on this bill were enclosed with more appreciative and approving statements on the government and political leadership's role in bringing this bill to the parliament ${ }^{\mathrm{ti}}$. Due to this mutual alliance between the two 
categories of leaders, those who were critical of this bill, mainly the monks from various Nikayas, had strongly criticized both lay and monastic leadership.

The criticisms leveled against Mahanayakas have been expressed along the lines of their leadership, politicization, knowledge, possession of wealth and social work etc. Monks like Alle Gunawansa, Yatawatte Dhammananda, Bengamuwe Nalaka and a number of young monks including university monks had expressed their dissent related to above-mentioned themes. They include accusations such as - Mahanayakas never took the lead for national problems, Mahanayakas are working with the government to chop off Buddhism and tame the monks, they are supporting the neoliberal political-economic agenda of the government, Mahanayakas have historically served the interests of the colonial and postcolonial leaders, they do not have the courage to point out the wrongdoings of politicians, they are unable to guide and give directions to young monks, do not provide acceptable solutions to the problems in monasteries ${ }^{\mathrm{iii}}$ and only concerned about unrighteous monk's damage to their Nikaya, which is predominantly based on caste, and not to Buddhism at large etc.

A young monk from University Bhikku Federation contended the role of Mahanayakas, in a media briefing, saying that

"They are telling that monks should not do business activities. But we ask who is actually doing business activities? Whether you or us? There can be monks who are doing a little vegetable farm (elawalu koratuwa) and feeding small monks. This bill can even restrict such activities. We are asking what right you have to say like this. Mahanayakas do not have a right because they possess 'Nindagam', (traditionally acquired land). If we go around Colombo there are so many people living in slums but what those monks had done to these Buddhists? Have they given a single piece of land from their 'Nindagam'? Having acres of tall walls and pandals built around their temples, they preach us about 'Dukkha'. What a joke."

He further questioned what Mahanayakas had done for the benefit of the people suffering from chronic kidney disease in the north-central region of Sri Lanka with their traditionally acquired wealth. The majority of the people those who suffer from the disease are Buddhists, and this young monk attempted to raise some moral questions about the just use of the Mahanayakas' traditionally acquired wealth and their commitment towards social work.

The current research agenda in the study of Buddhism represents a world of competing debates and discursive formations of what Buddhism is in local terms. It is more interested in understanding what Buddhists have to tell about Buddhism, how Buddhists get involved in different sociopolitical ventures, and how certain definitions about Buddhism get prominent while others get weakened in shifting conjunctures (De Silva, 2006). These pieces of evidence point out that some monks were not happy with the traditional authority of the institutional Buddhism at this conjuncture. However, it does not mean all the monks those who criticized the Mahanayakas are always against them or they can be labeled as radical monks. In fact, some of the monks those who made such comments have met and asked the assistance of Mahanayakas in other occasions for different issues. The point is that these criticisms might look different in another conjuncture but at this situation the actors those who had opposed the bill strategically resorted to criticizing Mahanayakas as it supported their agenda over the issue of this bill. As Abeysekara (2002) argues, the different formations of religion simply do not deny 'difference' but rather create it to 'undo' the very existence of that otherness. Here when responding to the difference over the issue of the draft bill, the actors reproduced the identity of the Mahanayakas, with adverse references, so as to overrule them at this particular conjuncture to ensure that their interpretation dominates over the other.

However, when we see the state of affairs of monastic reforms at this point, these views seemed to have suggested that the perceived legitimacy of Mahanayakas stood as an important factor when attempting to make changes to the monastic community of Sri Lanka. Also, looking at the critiques over the monastic leadership, one can argue that the effort to reform at this time invoked deeper reforms as opposing monks highlighted the reforms that are in need of at the level of its community's traditional authority. Therefore, one could infer from 
the debate that the attempt to reform in fact led to an implicit demand for deeper reforms in the monastic community, especially with respect to its traditional authority.

\section{Government and Political Leaders' Legitimacy}

The monks those who opposed the bill contested the government and the political leadership by arguing that it is inappropriate for those who are in the legislature to make laws related to Buddhists monks or 'Maha Sangha'iv . Further to that several monks and nationalist politicians made supporting views to this argument as they questioned how Non - Buddhists in the government and those who do not even live according to the five precepts or 'Pansil' could bring laws to control Buddhist monks in the country ${ }^{\mathrm{v}}$. This argument not only posed a challenge to this particular way of lawmaking on 'Kathikawath' but also to any similar effort where a legal framework to be made on monastic matters in time to come. It implies a separation of lay and monastic worlds in a manner in which the lay political world was considered inferior and has no legitimacy to make laws pertaining to the sacred monastic community.

Yet, those who advocated for the proposed bill seemed to have attempted to emphasize the values of democracy to construct a counter-argument. For example, in an interview with a local newspaper, a monk called Diviyagaha Yasassi responding to a question on Non - Buddhists voting to pass the bill said that

"Enacting laws is the duty of the parliament. They get appointed form the votes of the people and they have the supreme authority. We cannot suggest abolishing the supreme authority of the people. On the other hand, this is not something related to doctrine. This is about the procedure. In order to decide what is good and bad; they do not have to be Buddhists ${ }^{\text {vi, }}$

Here, this statement seems to suggest that the idea about good and bad is something beyond religion and people do not necessarily have to be Buddhists to make decisions on what is good and bad. In a way, it locates people with the ability to decide what is good and bad above the religious affiliations in a higher level so they can make right decisions on procedures related to religions. Moreover, it implies that the power of popular consent stands above the religious institutions.

This reminds what David Scott (1999) tells about the formation of narratives or counter-narratives. The Nietzschean idea that he refers, which is "the past is a storage closet where all costumes are kept". The actors in social debates have accustomed to taking the appropriate outfit from the larger closet, which assures their present. This discursive play is observable when we look at the above statement as the counter-argument borrowed its costumes from liberal, democratic and humanistic discourses. The reference to the supremacy of parliamentary system, the authority of the people and considering them as agents who could transcend the religious boundaries to decide what is good and bad shows how this actor has resorted to a particular discursive space to counter the opposing views. If someone approaches the issue from a religious point of view the first perspective, which is about denying the right of non-Buddhists and those who do not even have 'pansil' for bringing laws, might sound as the correct idea; whereas for someone who approaches the same issue from a more secular point of view might see the second view, which is about the supreme authority of the parliament and people, as the correct idea. Therefore, depending on how the reader of these contending views interpellated by the ideology, he or she may find one of these as consistent with his or her thinking. The actors' displacement into different discursive spaces can create multiple realities over the contested issues, which can be appealing to different people in different ways.

\section{Contradictions Over the Constitutionality of the Draft Bill}

As heated discussions and arguments started to unfold over the issue of this proposed Bill, three people including a Buddhist monk petitioned the Supreme Court of Sri Lanka by challenging the constitutionality of the Bill. The supreme court concluded that articles in the bill which reflect state interference to internal affairs of the religious institution, manner of conducting inquiries, punishments for violations, state appointing officials to 
examine Kathikawath stand in contrast to Article 9, 1014 (1) (e) of the constitution and need two-thirds majority in Parliament and a referendum for their enactment.

When we examine the constitution of Sri Lanka, it has reconciled two incompatible goals in the form of legal rhetoric. On one hand it gives special protection to the majority's religion Buddhism in article 09, and on the other hand, it provides equal protection for individual religious beliefs and worship practices for all Sri Lankans in articles 10 and 14 (1) (e). Therefore, rather than easing out, this constitutional nature has increased the complexities with respect to the issues that it intended to settle (Schonthal, 2014). This reference to two discursively produced religious claims in the constitution became a source of protection for those who opposed the bill at this time. Ironically, actors known for promoting more exclusivist form of religious ideas in the country at this time sought protection also from the individual religious rights part in the constitution when defending their position. They more than the other aspect, highlighted that the bill challenges the constitution's provisions on individual religious freedom. However, when it comes to previous conjunctures, like the issue over evangelical religious activities in the country, the petitioners' affiliated political parties selectively ignored this particular aspect of religion in the constitution and highlighted the idea that is 'Sri Lanka is a Buddhist country'. This also affirms what David Scott (1999) and Ananda Abeysekara (2002) argued - that in 'contending conjunctures' actors strategically resort to their fitting discourses. Here evidence suggests that they may even affirm the values in some previously hostile discourses depending on their interests.

As actors shift across the discursive spaces provided in legal frameworks, the reformists need to take such possibilities into account. Now the issue has once again come to where it was - as from the point of view of Mahanayakas or other senior monks - the problem of how to control the various undisciplined monks and various acts conducted by them still remains unresolved with further complexity.

\section{Problems of Traditionalism and Modernization of the Buddhist Monastic Community in Sri Lanka}

When it comes to problems over traditionalism and modernization of the Buddhist monastic community, some have argued that certain traditional activities done by monks such as astrology, horoscope reading, Seth Kavi (the blessings sung in the form of poems) and some indigenous medical treatments might come under risk as they can be interpreted as occult activities. On the contrary, those who advocate for a purified form of Buddhism argue for divesting Buddhism and monks from above-mentioned practices.

In addition, some inquired how a modern practice like monks' involvement in politics, contesting elections and holding Member of Parliament positions got sidelined from this bill ${ }^{\text {vii }}$. The involvement of monks in the realm of politics as active agents or contestants has not been considered seriously in the draft bill as a matter of significance, and it did not even find any resonance in this public debate. A theme like 'politics', which was considered to be important in earlier debates about monks' social position and behavior, got sidelined from the discursive space of this debate.

Looking at the accounts of Smith (1966), Bechert (1970), Swearer (1991) and Carrithers (1983) on Buddhism, politics, and modernity, Abeysekara (2002) explained how they, in their respective ways, envisaged dissociation or purification of religion from politicization. They, in fact, authorized it as the kind of reformation required in rediscovering the real identity of Buddhism and authentic monastic life. However, he was skeptical about taking these categories of 'authentic Buddhism and political Buddhism', as distinctly visible realities, and argued that varying debates in different 'conjunctures' characterize the shape of Buddhism. Persisting with this rather new approach towards religion, Abeysekara looked at the concept of 'reform' as a discursive characteristic. He contended that the other scholarly attempts had taken for granted the discursive roots of the term 'reform' and opposed for discerning it as a true religious activity. The evidence confirms this rather new argument of Abesekara; as the theme politics sidelining from the discursive space of reform at this time seemed to have suggested that actors do not put much weight on politics when it comes to 'reform' in comparison to previous situations. Therefore, despite what scholars have envisaged in earlier situations, the themes that 
become prominent in different situations in the history of monastic reforms are discursively produced and thus the concept of reform needs to be considered as a 'discursive characteristic'.

In addition, the section in the bill over obtaining driving license shows the way in which discourse works according to the structure. Here, the bill has defined obtaining a driving license as something inappropriate for a monk; yet Sri Lankan Buddhists monks, those who are considered to be involved in Buddhist Missionary activities (Dharmapracharaya), in western countries, obtain driving licenses and drive vehicles. Therefore, the same principle which contests monk's proper behavior is not applied when they are in western countries. Moreover, a few decades ago laymen were not happy about monks having televisions and radios in their temples and it was considered to be inappropriate for them. Today, donating televisions and radios to temples has become a very common thing among Buddhist laymen ${ }^{\text {viii }}$.

Though one could argue that there is plenty of space for modern interventions in present day Buddhism i.e. Uyangoda (2007), there is an incompatibility between reconciling traditional and modern values that had influenced the monastic community. The ancient kings might have had the power to be more forceful in reforming the monastic society and also the monastic leaders in this matter, yet in a modern state with the influence of liberal and democratic values, the similar effort might be challenging. One could say the evidence revealed how Mahanayakas wanted to maintain their influence and stronghold, yet failed with liberal democratic constitutionalism.

Therefore, the traditional Buddhist leadership needs to think about the manner in which Buddhism should adjust according to the shifting conjunctures of democratic modernity so as to conduct necessary reforms especially in a legal framework that hardens religious conflict; though it intended otherwise. Finally, the debate reflects that the traditional monastic institution is struggling to adjust with the modern state's legal framework when it comes to monastic reforms.

\section{Conclusion}

Overall, this social debate over the 'Theravada Bhikkhu Kathikawath (Registration) Bill' reveals that the actors those who opposed the bill had reproduced the identity of the Mahanayakas, with adverse references, so as to overrule them at this particular conjuncture to ensure that their interpretation dominates over the other. With that effort, the proponents' attempt to reforms in the monastic community was in a way confronted with implicit demands for deeper reforms in the community, especially with respect to its traditional authority. In addition, the contestation of government and political leaders' legitimacy shows how actors have resorted to alternative discursive spaces to counter the opposing views and how their displacements can create different realities over the contested issue. Moreover, the issue of constitutionality of the bill illustrated the way in which actors strategically resorted to their fitting discourse in 'contending conjunctures'. The evidence also suggested how actors tend to affirm the values in some previously hostile discourses depending on their interests. Finally, the identified themes over traditionalism and modernization showed that actors have not put much weight on politics when it comes to 'reforms' at this point of time in comparison to previous occasions, which also invites us to consider the concept of reform as a discursively produced characteristic in religion.

\section{References}

Abeysekara, A., 2002. Colors of the Robe: Religion, Identity and Difference (Columbia: University of South Carolina Press).

Bechert, H., 1970. Theravada Buddhist Sangha: Some General Observations on Historical and Political Factors in Its Development. Journal of Asian Studies, 29(No 4), pp.761 - 78.

Carrithers, M., 1983. The Forest Monks of Sri Lanka: An Anthropological and Historical Study (New Delhi: Oxford University Press).

De Silva, , 2006. Anthropology of 'Sinhala Buddhism'. Contemporary Buddhism, 7(No 2). 
Schonthal, , 2014. Constitutionalizing Religion: The Pyrrhic Success of Religious Rights in Postcolonial Sri Lanka. Journal of Law and Religion, 29(2), pp.1 - 21.

Scott, , 1999. Dehistoricizing History. In Refashioning Futures: Criticism after Postcoloniality (New Jersey: Princeton University Press), Ch. 04. pp.93 - 105.

Smith, E.D., 1966. South Asian Politics and Religion (Princeton: Princeton University Press).

Swearer, D., 1991. Fundamentalistic Movements in Theravada Buddhism. In Martin, E.M. \& Appleby, R.S. Fundamentalisms Observed (Chicago: University of Chicago Press), Ch. 11.

Uyangoda, J., 2007. Paradoxes of Buddhism. In Uyangoda, J. Religion in Context: Buddhism and Socio Political Change in Sri Lanka (Colombo: Social Scientists' Association). pp.1-5.

${ }^{i}$ See the following news reports for evidence Lakbima 19/01/2016 p 05, Lankadeepa 21/01/2016, Rivira 21/01/2016 p. 06, Diwayina 21/01/2016 p. 03, Rivira 02/02/2016 p.09, Lakbima 01/02/2016 p.05, Dinamina 03/02/2016 p.07 and Lakbima 03/02/2016 p. 05.

ii See the views of Malwaththa Chief prelate - Lankadeepa 25/01/2016, Rivira 25/01/2016, Dinamina 25/01/2016 p 01, 04; Asgiri Chief Prelate - Lankadeepa 25/01/2016, Dinamina 26/01/2016 p. 01, 04; Chief Prelate of Ramannya Nikaya - Dinamina 20/01/2016 p. 01, 04, Lakbima 29/01/2016 p.02, Chief Prelate of Amarapura Maha Nikaya Dawuldena Ganissara - Dinamina 03/02/2016 p. 02.

iii The Chief Incumbent of Bahirawakanda Sri Sambhodi Temple Yatawatte Dhammananda said that if the proposed bill is passed then it will be a major cause for degradation of the Buddhasasana. For him - if legal status is going to be vested upon the decisions taken by Mahanayakas and the Sangha Sabhas, then it will lead to conflict between Nikayas and monks. It is difficult to assume that Mahanayakas and Sangha Sabhas will give right decisions. Therefore, a Kathikawath composed after discussing with few people can lead to pragmatic issues. There is no issue about giving legitimacy to currently existing Kathikawath. The problem is with what is inside in those Kathikawath. In many occasions when the problems in monasteries were presented to Mahanayakas, they have not given acceptable and just solutions. See: 21/01/2016, Dinamina Visheshanga p. 14.

iv For the views of Bengamuwe Nalaka and Galabodaatte Ganasara, see: 14/01/2016, Lankadeepa. Also see Ranpathvila Wimalaratana's views in 28/01/2016, Lankadeepa.

v For example see: Deepa Wasanthi Edirisinghe referring to Udaya Gammampila in 20/01/16 Rivira and Volter Dayaratne referring to Pagoda Janththavansa in 28/01/2016, Dinamina p. 05.

${ }^{\text {vi }}$ For the views of Diviyagaha Yasassi see: 21/01/2016, Dinamina Visheshanga, p. 14.

vii See the views of Hagoda Vipassi in 15/01/2016 Lakbima p. 02.

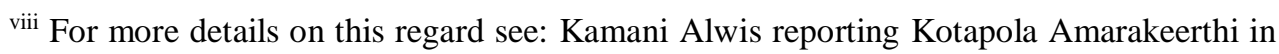
22/01/2016, Dinamina p. 09. 